\title{
EXPERIMENTAL INVESTIGATION OF INTERFACIAL FRICTION BETWEEN FRPs-WRAPPED STEEL SURFACE AND COHENSIONLESS SOIL
}

\author{
EKSPERIMENTALNA RAZISKAVA TRENJA NA MEJNI PLOSKVI \\ MED POVRŠINAMA S POLIMERI (FRP) OVITEGA JEKLA IN \\ NASUTE ZEMLJINE
}

\author{
Annie Sweetlin Jebarani Joshua Pannirselvam ${ }^{1 *}$, Daniel Thangaraj Duraisamy² \\ ${ }^{1}$ Velammal College of Engineering and Technology, Madurai to Rameshwaram Highway, Viraganoor, Madurai 625009 , India \\ ${ }^{2}$ Anna University College of Engineering Tindivanam, Tamil Nadu, India
}

Prejem rokopisa - received: 2019-10-31; sprejem za objavo - accepted for publication: 2020-06-17

doi:10.17222/mit.2019.264

\begin{abstract}
Steel piles are nowadays commonly used as a foundation component. The soil and steel surface interaction plays a major role in transferring the load to the soil. This study was carried out to examine the interfacial frictional behaviour of cohesionless soil and a steel surface wrapped with different types of fibre-reinforced polymers (FRPs). Conventional direct-shear tests were conducted on steel plates wrapped with FRP sheets. Fibre-reinforced polymers like unidirectional carbon, basalt, aramid and glass were wrapped on steel plates and tested at different orientations with respect to the applied shear. Two different soil samples were taken for the study, viz., well-graded and poorly graded sand. The experimental results showed that the interface friction increased with the surface roughness and also with the orientation of the fibres to the loading direction. The study also showed that the gradation of sand plays a vital role in the interfacial shear strength of the sand and steel surface wrapped with different types of fibre-reinforced polymers.

Keywords: interface friction, fibre-reinforced polymers, surface roughness, shear strength
\end{abstract}

Jekleni piloti se danes pogosto uporabljajo za temeljenje različnih komponent. Interakcija med zemljino (na primer rečnim peskom, mivko itd.) in površino jekla, igra glavno vlogo pri prenosu obremenitve s pilotov na zemljino. V članku avtorji opisujejo študijo ugotavljanja trenja na meji med nasuto zemljino in jekleno površino, oblečeno v različne vrste $z$ vlakni ojačanih polimerov (FRP; angl.: Fiber Reinforced Polymers). Za meritve so uporabili direktni strižni preizkus z različno orientacijo strižne obremenitve. Jeklene površine so bile oblečene v polimere ojačane z ogljikovimi, bazaltnimi, aramidnimi ali steklenimi vlakni. Uporabili so dve različni vrsti zemljine, kakovosten in manj kakovosten pesek. Eksperimentalni rezultati so pokazali, da trenje na mejni ploskvi narašča s povečano hrapavostjo površine in prav tako v odvisnosti od orientacije vlaken glede na obremenitev. Študija je prav tako pokazala, da kakovost izbranega peska pomembno vliva na strižno trdnost na mejni ploskvi med peskom in jeklom, oblečenim z različnimi vrstami polimerov ojačanih z vlakni.

Ključne besede: trenje na mejni ploskvi, z vlakni ojačani polimeri, površinska hrapavost, strižna trdnost

\section{INTRODUCTION}

Steel piles transfer load to the adjacent soil by interface friction. Hence the study of this interface shear strength is necessary to increase the structural capacity of the piles. This has been done basically with simple shear studies like a direct-shear test on steel surfaces and both cohesive and non-cohesive soils. The emerging technology of fibre-reinforced polymers also added to the strength and durability of steel piles. Fibre-reinforced polymers have special physical characteristics like high strength, non-corrosive, viscoelastic behaviour and light weight. Hence, they find wide applications in civil engineering. Fibres can be natural or artificial. Artificial fibres are mostly used in civil-engineering applications as natural fibres can decompose in the course of time. The strength of these fibres vary with their orientation with regard to the loading direction. Recently, studies

*Corresponding author's e-mail:

jpas@vcet.ac.in (Annie Sweetlin Jebarani Joshua Pannirselvam) have been done to determine the behaviour of the fibres wrapped on a steel surface and their interaction with the adjacent soil; their results are discussed in this paper. The roughness of the interacting surface is of crucial importance in geotechnical terms. This paper also attempts to study the effects of surface roughness and soil gradation on the interface shear strength and friction angle of fibres.

M. Uesugi and H. Kishida ${ }^{1}$ did laboratory experiments on the friction between dry sand and mild steel. They also studied the possible influences of surface roughness of steel and particle size on the interfacial shear strength. T. D. O'Rourke et al. ${ }^{2}$ did experiments on sand-polymer interfaces using direct-shear tests and found that the interface shear strength increased with the soil density and surface hardness. J. D. Frost and J. Hans $^{3}$ did experiments on the interface behaviour of sand-FRP interfaces and found that the interface shear strength depends on the relative roughness of surface, initial density of soil mass, angularity of soil particles 
and normal stress level. M. A. Pando ${ }^{4}$ did experiments on the interaction between FRP composite piles and sand and found that the surface roughness along with surface hardness and angularity of soil influenced the interface friction angle. I. Nishizaki and S. Meiarashi ${ }^{5}$ studied a long-term deterioration of GFRP in water and moist at various temperatures and in immersed conditions. The study showed that at $60{ }^{\circ} \mathrm{C}$ cracks appeared in the specimen but no chemical changes occurred. D. Porcino et al. ${ }^{6}$ did experiments on natural silicas and aluminium plates of different roughness degrees under a constant normal load and constant normal stiffness. They found that the surface roughness influences the interface shear strength between the soil and solid. Narayan Prasad Sahu et al. ${ }^{7}$ studied the durability of aramid-fibre-reinforced polymers wrapped on concrete specimens on the corrosion and found that it is highly resistant. Y.-K. Li et al. ${ }^{8}$ researched the interfaces between soils and steel, focusing on the friction resistance between them. The test results showed that the peak and residual friction angle increase with an increase in the surface roughness and decrease in the surface hardness. The friction angle reaches the largest value with the largest surface roughness. V. S. Quinteros et al. ${ }^{9}$ did experiments on the steel-sand interface, using Bishop's ring shear apparatus to obtain the residual-friction angles. They found that the residual-friction angle depends on the surface roughness and effective vertical stresses, but it is independent of fines content. F. Han et al. ${ }^{10}$ did experiments on the shear strength of sand-steel interface using ten different types of sand and found that the surface roughness, soil gradation and particle size are influential parameters. H. S. Aksoy et al. ${ }^{11}$ performed a direct-shear test to find the internal friction angle, interface shear test and skin-friction angle between made-up soil samples and steel-FRP piles. They found that as the percentage of clay increases, the skin-friction angle reduces. J. P. A. Jose et al. ${ }^{12}$ studied the performance of a basalt-fibre-reinforced polymerconcrete specimen and found a significant increase in the shear strength as the roughness of the interface increased.

\section{MATERIAL PROPERTIES}

Two types of soil samples were tested: sand from a field and ordinary river sand. Preliminary tests were conducted to find the index properties of both types of cohesionless soil, which are listed in Table 1. In addition, we chose carbon-fibre-reinforced polymer (CFRP), glass-fibre-reinforced polymer (GFRP), basalt-fibre-reinforced polymer (BFRP) and aramid-fibre-reinforced polymer (AFRP). All the fibres were unidirectional. The properties of all the fibres are listed in Table 2. Mildsteel plates with a size of $6 \times 6 \times 0.6 \mathrm{~cm}$ were used in the experiments.

\section{METHODOLOGY}

The absolute surface roughness $\left(R_{\mathrm{a}}\right.$ in $\left.\mu \mathrm{m}\right)$ of the steel surface and steel plates wrapped with different FRPs were found using a surface roughness meter Mitutoyo brand for both orientations. The meter has a needle that moves over the surface and the running values are printed as a digital output in the wave form. It also gives the average value of $R_{a}$ as a digital display, considered to be the result. As the soil was classified as the SP and SW sand, as per IS 2720 Part XIII-1983, the direct-shear test was adopted to find the shear strength of the soil and, hence, the interface-friction angle. A study of the interface frictional strength was carried out in a conventional direct-shear apparatus, as per IS 2720 Part XIII-1983, with a shear box with a size of $(6 \times 6 \times 2) \mathrm{cm}$

Table 1: Index properties of the sand

\begin{tabular}{|c|l|c|c|}
\hline S. No. & \multicolumn{1}{|c|}{ PROPERTIES } & RIVER SAND & FIELD SAND \\
\hline 1 & Particle size $D_{10}$ & 0.2 & 0.17 \\
\hline 2 & Particle size $D_{30}$ & 0.5 & 0.45 \\
\hline 3 & Particle size $D_{60}$ & 0.7 & 6.1 \\
\hline 4 & Uniformity coefficient, $C_{\mathrm{u}}$ & 3.5 & 1.065 \\
\hline 5 & Coefficient of curvature, $C_{\mathrm{c}}$ & 1.78 & 2.58 \\
\hline 6 & Type of soil $($ as per $1498-1970)$ & Poorly graded sand (SP) & Well graded sand (SW) \\
\hline 7 & Specific gravity & 2.62 & 13.83 \\
\hline 8 & Relative density & $50 \%$ & 12.85 \\
\hline 9 & Maximum density $\left(\mathrm{kN} / \mathrm{m}^{3}\right)$ & 19.42 & 13.32 \\
\hline 10 & Minimum density $\left(\mathrm{kN} / \mathrm{m}^{3}\right)$ & 13.54 & \\
\hline 11 & Test density $\left(\mathrm{kN} / \mathrm{m}^{3}\right)$ & 16.40 & \\
\hline
\end{tabular}

Table 2: Properties of the fibres

\begin{tabular}{|c|l|c|c|c|c|}
\hline S. No. & \multicolumn{1}{|c|}{ Fibre property/type } & CFRP & GFRP & BFRP & AFRP \\
\hline 1 & Fibre thickness $(\mathrm{mm})$ & 0.3 & 0.6 & 0.33 & 0.5 \\
\hline 2 & Fibre orientation & Unidirectional & Unidirectional & Unidirectional & Unidirectional \\
\hline 3 & Tensile strength $\left(\mathrm{kN} / \mathrm{m}^{2}\right)$ & $3500 \times 10^{3}$ & $3400 \times 10^{3}$ & $1500 \times 10^{3}$ & $2500 \times 10^{3}$ \\
\hline 4 & Tensile modulus $\left(\mathrm{kN} / \mathrm{m}^{2}\right)$ & $238 \times 10^{6}$ & $73 \times 10^{6}$ & $86 \times 10^{6}$ & $131 \times 10^{6}$ \\
\hline
\end{tabular}




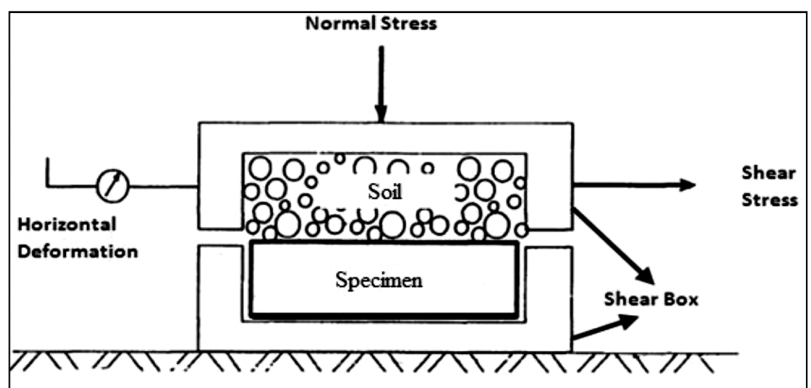

Figure 1: Experimental set-up for the direct-shear test

and the steel-plate specimen with the size of $(6 \times 6 \times 0.6)$ $\mathrm{cm}$. The experimental set-up is shown in Figure 1. The shear test was conducted for control samples SW sand/SW sand, SP sand/SP sand, steel/SW sand and steel/SP sand. Then the steel plates were wrapped with different FRPs using epoxy resin as shown in Figure 2a. The plates were placed in the apparatus at orientations of $0^{\circ}$ and $90^{\circ}$ to the loading direction. The direct-shear test was done at normal stresses of $(50,100,150,200) \mathrm{kN} / \mathrm{m}^{2}$ for all the samples. The sheared samples are shown in Figure 2b. The horizontal displacement was measured using a dial gauge. The interface friction angle was found as the slope of line from the graph plotting the normal stress as the abscissa and the shear stress as the ordinate.

\section{RESULTS AND DISCUSSION}

\subsection{Interface-friction angle and fibre orientation}

The interface-friction angle was found for the plain steel samples with well-graded and poorly graded sands and also for the steel samples wrapped with different FRPs. The results for the internal-friction angle for the fibre orientation parallel and perpendicular to the loading direction are presented in Table 3. The results showed that the interface friction of the fibre-wrapped specimens was higher than that of the control specimens for both types of sand. It was also found that, on average, the interface-friction angles of the fibres with the perpendicular orientation were about $10 \%$ higher than those of the fibres with the parallel orientation.

Table 3: Interface-friction angle and surface roughness

\begin{tabular}{|c|c|c|c|c|}
\hline \multirow{2}{*}{ S. No. } & \multirow{2}{*}{ Material } & \multirow{2}{*}{$R_{\mathrm{a}}(\mu \mathrm{m})$} & \multicolumn{2}{|c|}{$\begin{array}{c}\text { Interface-friction angle in } \\
\text { degrees }\end{array}$} \\
\cline { 4 - 5 } & & $\begin{array}{c}\text { Poorly } \\
\text { graded sand }\end{array}$ & $\begin{array}{c}\text { Well-graded } \\
\text { sand }\end{array}$ \\
\hline 1 & STEEL & 0.631 & 14 & 22 \\
\hline 2 & CFRP 0 & 0.743 & 21 & 22 \\
\hline 3 & CFRP 90 $^{\circ}$ & 0.978 & 26 & 26 \\
\hline 4 & BFRP 0 & 2.436 & 23 & 29 \\
\hline 5 & BFRP 90 & 2.911 & 29 & 30 \\
\hline 6 & AFRP 0 & 5.875 & 29 & 30 \\
\hline 7 & AFRP 90 & 6.31 & 31 & 33 \\
\hline 8 & GFRP $0^{\circ}$ & 8.874 & 30 & 33 \\
\hline 9 & ${\text { GFRP } 90^{\circ}}^{\circ}$ & 9.312 & 33 & 37 \\
\hline
\end{tabular}

\subsection{Influence of the surface roughness on the friction angle}

The absolute surface roughness $\left(R_{\mathrm{a}}\right.$ in $\left.\mu \mathrm{m}\right)$ of the plain steel surface and steel plates wrapped with different FRPs and different fibre orientations was found using a surface-roughness meter; the results are given in Table 3. They show that as the value of surface roughness increased, the internal-friction angle also increased. Also, the values of the surface roughness are slightly higher for the fibres with the $90^{\circ}$ orientation than those with the $0^{\circ}$ orientation, as represented in Figure 3. In addition, as the gradation of the sand varies, the interface friction a)

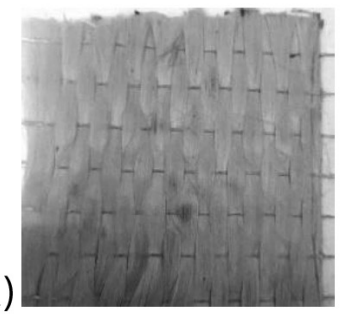

e)

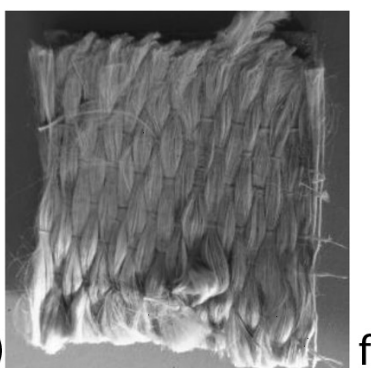

b)
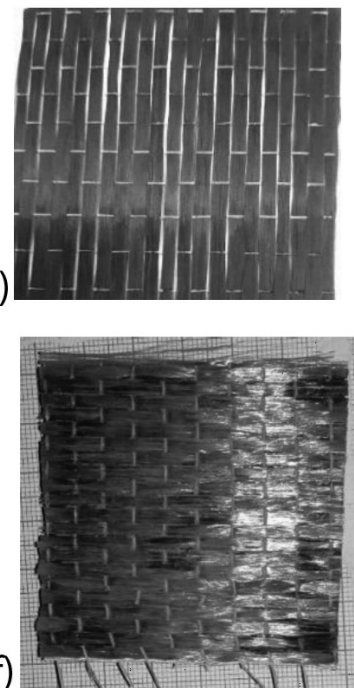

C)
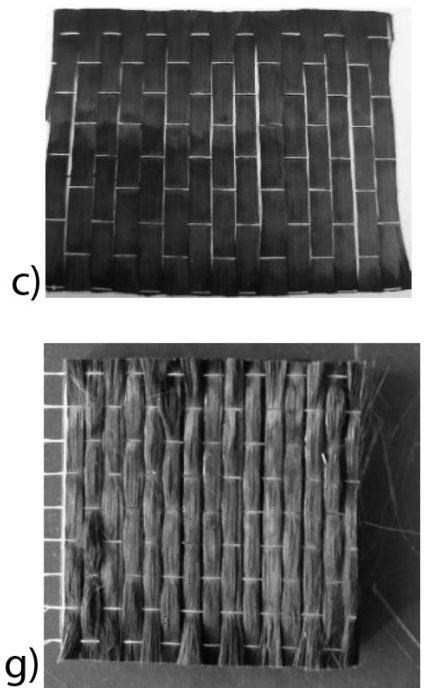

d)

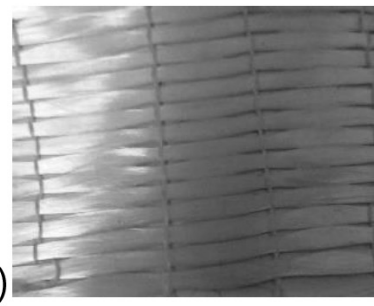

h)

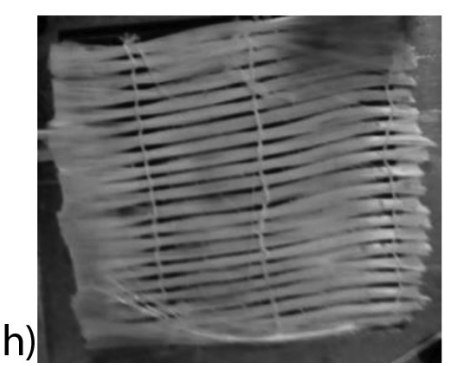

Figure 2: FRPs wrapped on the steel plates before the test: a) aramid, b) basalt, c) carbon, d) glass and FRPs wrapped on the steel plates after the test: e) aramid, f) basalt, g) carbon, h) glass 


\section{A. S. J. J. PANNIRSELVAM et al.: EXPERIMENTAL INVESTIGATION OF INTERFACIAL FRICTION BETWEEN ...}

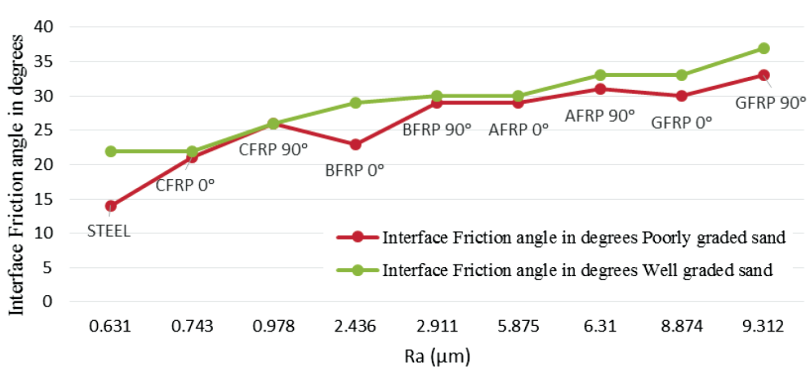

Figure 3: Effect of the surface roughness on the interface-friction angle

varies as well. Well-graded sand provides more resistance to shear than poorly graded sand.

\subsection{Variation in the shear stress and normal stress}

The conventional direct-shear test was conducted for various normal-stress values and the maximum shear stress was found. The variation in the normal and maximum shear stress for poorly graded sand and for the parallel fibre orientation is shown in Figure 4, while Figure 5 refers to the perpendicular fibre orientation. It was found that as the normal stress was increased, the maximum shear stress also increased. The tensile strength of fibres also has a significant impact on the interface friction. As the tensile strength of the glass fibres increased, it exhibited a higher value in both parallel and perpendicular orientations.

In the well-graded sand, the values of the shear stress were greater than in the poorly graded sand, clearly indicating that its shear resistance was higher. Also, when compared to the control specimen, the value of the glass-fibre specimen was nearly twice as big, which is more advantageous when used as the structural material. The variation in the normal and shear stress in the well-graded sand and for the parallel orientation is shown in Figure 6, while Figure 7 refers to the perpendicular orientation.

For both types of sand, the fibres with the perpendicular orientation gave higher values than the fibres with the parallel orientation. The maximum shear stress increased by $5 \%$ in the parallel direction and by $15 \%$ in

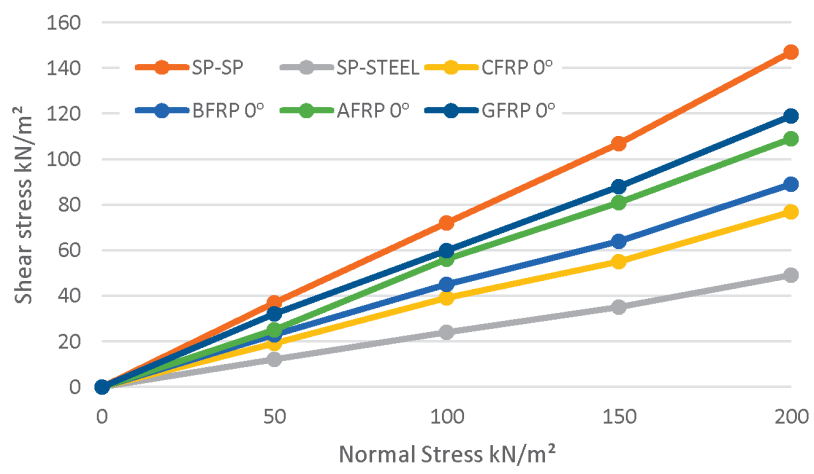

Figure 4: Normal versus maximum shear stress for $0^{\circ}$ in poorly graded sand

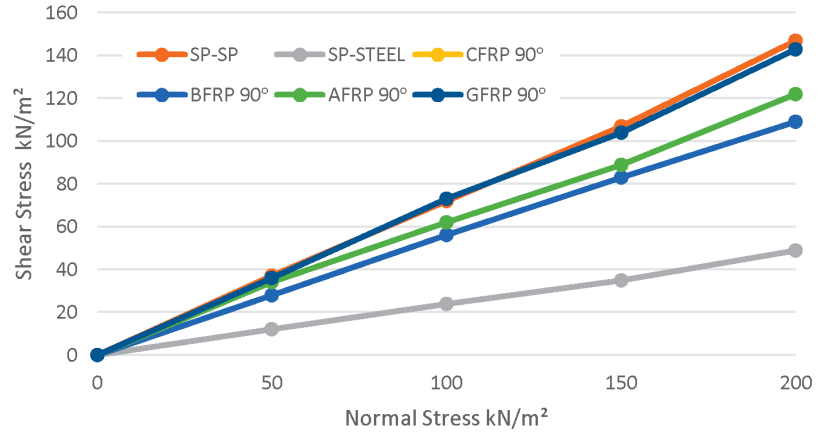

Figure 5: Normal versus shear stress for $90^{\circ}$ in poorly graded sand

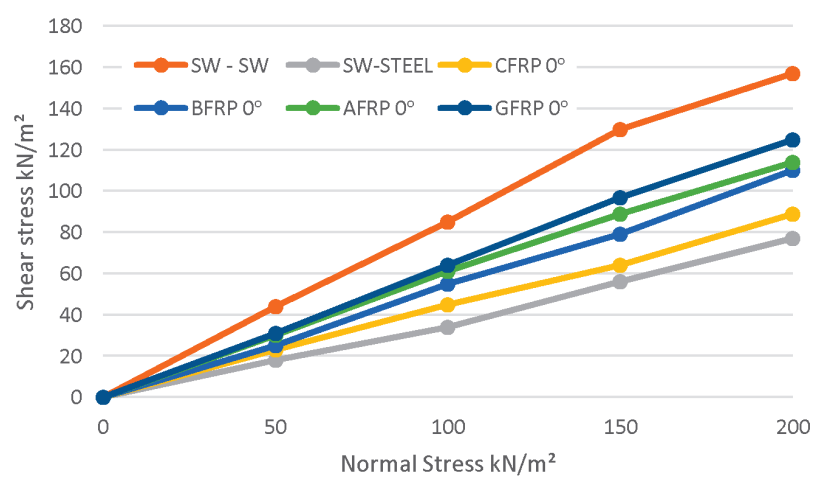

Figure 6: Normal versus shear stress at $0^{\circ}$ in well-graded sand

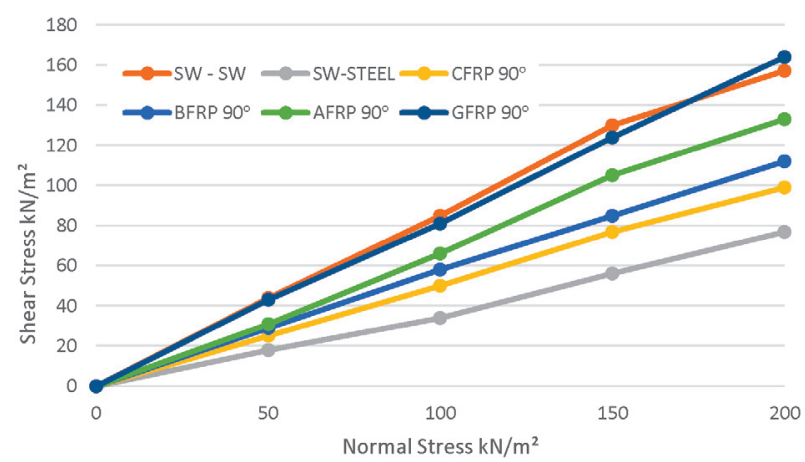

Figure 7: Normal versus shear stress at $90^{\circ}$ in well-graded sand

the perpendicular direction with respect to the soil gradation.

\section{CONCLUSIONS}

Conventional direct-shear tests were conducted to find the interface-friction angle between well or poorly graded sandy soils and steel-plate specimens wrapped with CFRP, BFRP, AFRP and GFRP. From the results obtained, it was seen that, in general, there was a larger increase in the angle of interface friction with the FRP wrapping in the perpendicular direction than in the parallel direction to the shear loading for all the types of fibres. There was also an increase in the shear strength at the interface with an increase in the surface roughness for all the types of fibre-wrapped steel specimens. The shear strength increases with the increasing normal 
stress. The lowest results were obtained for the CFRP specimen and the highest were obtained for the GFRP specimen.

For the CFRP specimen, the increase in the interface-friction angle for the parallel fibre orientation was $50 \%$ higher than that of the control specimen with an increase in the surface roughness in poorly graded sand. Similarly, the increase in the interface angle of the specimen with the perpendicular fibre orientation was $85 \%$ higher than that of the control specimen with an increase in the surface roughness in poorly graded sand, whereas no significant change was noticed for the well-graded sand.

The increase in the interface-friction angle of the GFRP specimen with the parallel fibre orientation was $114 \%$ higher than that of the control specimen in poorly graded sand. Similarly, the increase in the interface angle of the specimen with the perpendicular fibre orientation was $135 \%$ larger than that of the control specimen in poorly graded sand; in well-graded sand, the increase in the interface-friction angle of the specimen with the parallel fibre orientation was $135 \%$ higher than that of the control specimen in the well-graded sand, while the increase in the interface angle of the specimen with the perpendicular fibre orientation was $164 \%$ higher than that of the control specimen.

The experimental results show that the steel-FRP composite material exhibits a high surface roughness and interface friction, increasing its shear strength.

\section{REFERENCES}

${ }^{1}$ M. Uesugi, H. Kishida, Frictional resistance at yield between dry sand and mild steel, Soils and Foundations, 26 (1986) 4, 139-149

${ }^{2}$ T. D. O'Rourke, S. J. Druschel, A. N. Netravali, Shear strength characteristics of sand-polymer interfaces, J. Geotech. Engrg., 116 (1990) 3, 451-469

${ }^{3}$ J. D. Frost, J. Han, Behavior of interfaces between fiber-reinforced polymers and sands, Journal of Geotechnical and Geo-Environmental Engineering, 125 (1999) 8, 633-640

${ }^{4}$ M. A. Pando, G. M. Filz, J. E. Dove, E. J. Hoppe, Interface shear tests on FRP composite piles, Deep Foundations 2002, 1486-1500

${ }^{5}$ I. Nishizaki, S. Meiarashi, Long term deterioration of GFRP in water and moist environment, Journal of Composites for Construction, 6 (2002), 21-27, doi:10.1061/(ASCE) 1090-0268(2002)6:1(21)

${ }^{6}$ D. Porcino, V. Fioravante, V. N. Ghionna, S. Pedroni, Interface behavior of sands from constant normal stiffness direct shear tests, Geotechnical Testing Journal, 26 (2003) 3, 1-14

${ }^{7}$ N. P. Sahu, D. K. Khande, G. C. Patel, P. K. Sen, Study on aramid fibre and comparison with other composite materials, IJIRST, 1 (2014) 7, 303-306

${ }^{8}$ Y.-K. Li, X.-L. Han, J. Ji, D.-L. Fu, Y.-K. Qiu, B.-C. Dai, C. Lin, Behavior of interfaces between granular soil and structure: A state-of the-art review, The Open Civil Engineering Journal, 9 (2015), 213-223

${ }^{9}$ V. S. Quinteros, R. Dyvik, N. Mortensen, Interface friction angle soil-on-steel from ring shear tests on offshore north sea sands, Geotechnical Frontiers 2017, GSP, 280 (2017), 358-368

${ }^{10}$ A. M F. Han, S. M. E. Ganju, F. A. R. Salgado, A. M. M. Prezzi, Effects of interface roughness, particle geometry, and gradation on the sand-steel interface friction angle, J. Geotech. Geoenviron. Eng., 144 (2018) 12, 04018096, doi:10.1061/(ASCE)GT.1943-5606.0001990

${ }^{11}$ H. S. Aksoy, M. Gör, E. İnal, Determination of friction angles between soil and steel - FRP piles, Turkish Journal of Science \& Technology, 13 (2018) 1, 19-23

${ }^{12}$ J. P.h A. Jose, P. R. Prasanna, F. Prakash, Technical performance of basalt fibre reinforced polymer BFRP confined RC driven piles new construction technology, International Journal of Engineering and Technology, 7 (2018) 3, 1685-1689, doi:10.14419/ijet.v7i3.12628 